\title{
Chemical composition and seasonal variation of the volatile oils from Siparuna
}

\section{guianensis Aubl. leaves collected from Monte do Carmo, Tocantins}

\author{
Composição química e variação sazonal dos óleos voláteis das follhas de Siparuna guianensis Aubl. \\ coletadas em Monte do Carmo, Tocantins \\ Composición química y variación estacional de los aceites volátiles de Siparuna guianensis Aubl. \\ hojas recolectadas de Monte do Carmo, Tocantins
}

Received: 12/18/2021 | Reviewed: 12/27/2021 |Accept: 12/29/2021| Published: 01/07/2022

Joaquim Aurélio Tomaz de Souza

ORCID: https://orcid.org/0000-0003-3389-367X Universidade Federal de Goiás, Brazil E-mail: jatomazdesouza@hotmail.com

Liliane de Sousa Silva

ORCID: https://orcid.org/0000-0001-9497-7573 Universidade Federal de Goiás, Brazil Secretaria Estadual de Educação de Goiás, Brazil

E-mail: ssliliane@gmail.com

Camila Aline Romano

ORCID: https://orcid.org/0000-0002-3564-6368 Universidade Federal de Goiás, Brazil

E-mail: camilaalineromano@gmail.com

Luiz Carlos da Cunha

ORCID: https://orcid.org/0000-0002-1525-8528 Universidade Federal de Goiás, Brazil E-mail: lccunha@ufg.br

Jerônimo Raimundo Oliveira Neto

ORCID: https://orcid.org/0000-0002-0261-4554 Universidade Federal de Goiás, Brazil E-mail: jeronimoneto@gmail.com

Leonardo Luiz Borges

ORCID: https://orcid.org/0000-0003-2183-3944 Universidade Federal de Goiás, Brazil

Pontifícia Universidade Católica de Goiás, Brazil E-mail: leonardoquimica@gmail.com

Tatiana de Sousa Fiuza

ORCID: https://orcid.org/0000-0003-0135-177X Universidade Federal de Goiás, Brazil E-mail: tatianaanatomia@gmail.com José Realino de Paula

ORCID: https://orcid.org/0000-0002-4424-7692 Universidade Federal de Goiás, Brazil E-mail: pjrpaula@gmail.com

\begin{abstract}
Siparuna guianensis Aubl., known as "negramina", "capitu”, is a small tree used for headaches, colds, fevers, as a healing agent, insect, and tick repellents. This study aimed to evaluate the chemical composition and seasonal variability of essential oils from the leaves of S. guianensis. Botanical material was collected in Monte do Carmo, Tocantins, Brazil. The powder from the leaves was submitted to hydrodistillation in a Clevenger apparatus, and the identification of the compounds was performed by GC-MS. In volatile oils, $21.32 \%$ to $55.44 \%$ of sesquiterpenes, 19.95 to $49.73 \%$ of oxygenated sesquiterpenes, 0.48 to $1.55 \%$ of oxygenated monoterpenes, 0 to $5.67 \%$ of monoterpene hydrocarbons were identified, 0 to $48.2 \%$ of other compounds. The major compounds were $\gamma$-muurolene (13.99 to 35.97\%), Curzerene (7.22-19.15\%), Curzerenone (7.3-18.13\%), 2-undecanone (3.99- 10.63\%). The presence of two clusters was verified: cluster I, discriminated by the compounds Curzerenone, $\beta$-selinene, $\delta$-elemene, corresponding to the months with the lowest index, and cluster II, discriminated by the $\beta$-burbonene, corresponding to the months with the highest index rainfall index. Comparing the present study with data from the literature, it is concluded that $S$. guianensis presents great chemical variability, which can be explained by genetic factors, seasonality, light, temperature, which can alter the production of metabolites. As S. guianensis has broad therapeutic potential as an antimicrobial and promising larvicidal activity, there is a need for agronomic studies to obtain
\end{abstract}


specimens that require more interesting chemical components for the pharmaceutical industry. This study is the first carried out with oils from leaves collected in Monte do Carmo, Tocantins, Brazil.

Keywords: Siparunaceae; Essential oils; Insecticide; Negramin.

\section{Resumo}

Siparuna guianensis Aubl., conhecida como "negramina, capitu", é uma arvoreta utilizada para dor de cabeça, resfriado, febres, como cicatrizante, repelentes de insetos e carrapatos. Objetivou-se avaliar a composição química e variabilidade sazonal dos óleos essenciais das folhas de $S$. guianensis. O material botânco foi coletado em Monte do Carmo, Tocantins, Brasil. O pó das folhas foi submetido à hidrodestilação em aparelho de Clevenger e a identificação dos compostos voláteis obtidos foi realizada por GC-MS. Foram identificados nos óleos voláteis 21,32\% a 55,44\% de sesquiterpenos, 19,95 a 49,73\% de sesquiterpenos oxigenados, 0,48 a 1,55\% de monoterpenos oxigenados, 0 a 5,67\% de hidrocarbonetos monoterpenos, 0 a 48,2\% de outros compostos. Os compostos majoritários foram $\gamma$-muurolene $(13,99$ a 35,97\%), Curzerene (7,22-19,15\%), Curzerenone (7,3-18,13\%), 2-undecanone (3,99- 10,63\%). Verificou-se a presença de dois clusters: cluster I, discriminado pelos compostos Curzerenone, $\beta$-selineno, $\delta$-elemene, corresponde aos meses com menor índice pluviométrico, e o cluster II, discriminado composto pelo $\beta$-burbonene, corresponde aos meses com maior índice pluviométrico. Comparando o presente estudo com dados da literatura, conclui-se que a $S$. guianensis apresenta grande variabilidade química o que pode ser explicada por fatores genéticos, sazonalidade, luz, temperatura, que podem alterar a produção de metabólitos. Como a S. guianensis tem amplo potencial terapêutico como antimicrobiano e atividade larvicida promissora, há a necessidade de estudos agronômicos de forma a se obter espécimes que produzem compostos químicos interessantes em maior quantidade para indústria farmacêutica. Esse estudo é o primeiro realizado com os óleos das folhas coletadas em Monte do Carmo, Tocantins, Brasil.

Palavras-chave: Siparunaceae; Óleos essenciais; Inseticida; Negramina.

\section{Resumen}

Siparuna guianensis Aubl., Conocido como "negramina, capitu", es un pequeño árbol utilizado para dolores de cabeza, resfriados, fiebres, como agente curativo, repelente de insectos y garrapatas. El objetivo de este estudio fue evaluar la composición química y la variabilidad estacional de los aceites esenciales de las hojas de S. guianensis. El material botánico fue recolectado Monte do Carmo, Tocantins, Brasil. El polvo de las hojas se sometió a hidrodestilación en un aparato Clevenger y la identificación de los compuestos volátiles obtenidos se realizó mediante GC-MS. En los aceites volátiles, se identificaron $21,32 \%$ a $55,44 \%$ de sesquiterpenos, 19,95 a $49,73 \%$ de sesquiterpenos oxigenados, 0,48 a 1,55\% de monoterpenos oxigenados, 0 a 5,67\% de hidrocarburos monoterpenos, 0 a $48,2 \%$ de otros compuestos. Los compuestos principales fueron $\gamma$-muuroleno $(13,99$ a $35,97 \%)$, curzereno $(7,22$ a $19,15 \%)$, curzerenona (7,3 a 18,13\%), 2-undecanona (3,99 a 10,63\%). Se verificó la presencia de dos conglomerados: el conglomerado I, discriminado por los compuestos Curzerenona, $\beta$-selineno, $\delta$-elemeno, corresponde a los meses el índice de precipitación más bajo, y el conglomerado II, discriminado por el $\beta$-burboneno, corresponde a los meses con con mayor precipitación pluvial. Comparando el presente estudio con los datos de la literatura, se concluye que $S$. guianensis presenta una gran variabilidad química que puede ser explicada por factores genéticos, estacionalidad, luz, temperatura, que pueden alterar la producción de metabolitos. Dado que $S$. guianensis tiene un amplio potencial terapéutico como antimicrobiano y una actividad larvicida prometedora, es necesario realizar estudios agronómicos para obtener muestras que produzcan compuestos químicos interesantes en mayores cantidades para la industria farmacéutica. Este estudio es el primero que se lleva a cabo con aceites de hojas recolectadas en Monte do Carmo, Tocantins, Brasil.

Palabras clave: Siparunaceae; Aceites esenciales; Insecticida; Negramina.

\section{Introduction}

Siparuna guianensis Aubl. belongs to the Siparunaceae family and is popularly known as "negramina", "limão bravo", capitu". It is a small tree up to $7 \mathrm{~m}$ in height, slightly roughened bark, gray in color, simple leaves with a smooth margin, opposite and glabrous, small greenish flowers, fleshy fruit, indehiscent, multiple, drupoid type, seed up to 4 mm in length. Fruit maturation occurs in the rainy season from January to March. The predominant habitat is forest, occurring in Mata de Galeria, Mata Seca and Cerradão. Present in the Cerrado, Amazon, Caatinga, Atlantic Forest and Pantanal domains (Kuhlmann, 2012).

S. guianensis leaves are hypostomatic, covered by a thin layer of cuticle, stellate non-glandular trichomes (Bierase \& Sajo, 2009), capitate, and pelted glandular trichomes on both sides, and non-glandular trichomes (tectors), uniseriate, multicellular, unbranched, predominant in the abaxial epidermis. The secretory ducts, which are formed by elongated cavities resulting from the junction of several secretory, epithelial cells, being lined with adjacent cells (Portella et al., 2014). 
Epidermal cells on the adaxial surface show cells with straight anticlinal walls, in front view, and on the abaxial surface sinuous anticlinal walls. In the central vein, it presents a main vascular system in the form of an arch with a collateral bundle in an adaxial position. The petiole is covered by a thin cuticle showing the main vascular system in the form of a continuous arch with two collateral bundles in an adaxial position. It is verified that idioblasts contain phenolic compounds in the central vein, petiole, and intervein (Bierase \& Sajo, 2009).

The leaves, in the form of decoction and infusion, are indicated for headaches (blood coming out of the nose), colds (De La Cruz, 2008), as a healing agent (Kuhlmann, 2012), against pain and fever (slightly warm baths, as a relaxant and to relieve rheumatic, muscle and body pain) (decoction of 12-15 leaves/liter of water), to prevent lice in chicken nests, as insect repellents (Carvalho \& Vilarinho, 2017) and ticks (Kuhlmann, 2012), for digestive problems, snake bite (leaves), nasal congestion, cold, abortive (fruit), as an emetic (root) and for herpes ( shells) (Taylor, et al., 2006)

Chemical studies performed by Simas, et al. (2001) identified in fruit receptacles collected in Caratinga, Minas Gerais, Brazil, the alkaloids liriodenine, nantenin, N-methyl-laurotetanine, norglaucine, asimilobin, asimilobin, anonaine, nornantenine, and in fruit liriodenine, palmitic acid, acid linoleic acid, oleic acid, and stearic acid. Guimarães, et al. (2005) isolated from leaves collected in Crato, Ceará, Brazil the compounds quercetin, and two quercetin derivatives: quercetin, 3OßD-glucopyranosyl(6-1)-rhamnoside, 2, and 7-OßD-glucopyranosyl(6-1)-rhamnoside, kaempferol, and the monoglycoside of kaempferol (rhamnoside). Facundo, et al. (2012) isolated from S. guianensis leaves collected in Mirante da Serra, Rondônia, Brazil the compounds kaempferolmethylether, kumatakenina (kaempferol-3,7-dimethyl ether), and kaempferol-3,7,3'trimethylether. Marti et al. (2013) isolated from the leaves of $S$. guianensis collected in French Guiana the compounds (+) bulbocapnine, (+) - N-methylindcarpine, (+) - actinodafinine, liriodenine and (+) - 11-methoxynornoelistin. Conegundes, et al. (2021) identified S. guianensis leaves collected from Matias Barbosa, the compounds kaempferol-pentosyl-pentosiderhamnoside, kaempferol dirhamnoside, kaempferol-pentosyl-rhamnoside, rhamnosyl-caempferol and kaempferol dimethyl ether.

Taylor, et al. (2006) observed cytotoxic activity of the young leaf extract of S. guianensis for the SKBR3 breast cancer cell line. Andrade, et al. (2015) described antimicrobial activity of volatile oil from leaves against Listeria monocytogenes $\left(\mathrm{MIC}=250 \mu \mathrm{g} \mathrm{mL}^{-1}\right)$, Staphylococcus aureus $\left(\mathrm{MIC}=125 \mu \mathrm{g} \mathrm{mL}^{-1}\right)$, Aspergillus flavus $\left(\mathrm{MIC}=7.81 \mu \mathrm{gL}^{-1}\right.$ ), Aspergillus carbonarius $\left(\mathrm{MIC}=125 \mu \mathrm{g} \mathrm{mL}^{-1}\right)$, Aspergillus niger $\left(\mathrm{MIC}=31.25 \mu \mathrm{g} \mathrm{mL}^{-1}\right)$, Penicillium commune $(\mathrm{MIC}=31.25$ $\mu \mathrm{g} \mathrm{m}^{-1}$ ). Melo, et al. (2017) verified activity against Mycobacterium tuberculosis, Mycobacterium kansasii $(\mathrm{MIC}=500 \mu \mathrm{g}$ $\mathrm{mL}^{-1}$ ) and Mycobacterium avium ( $\mathrm{MIC}=250 \mu \mathrm{g} \mathrm{mL}^{-1}$ ), Moura, et al. (2020) against Escherichia coli, Pseudomonas aeruginosa, Streptococcus pyogenes $\left(\mathrm{MIC}=0.86 \mu \mathrm{g} \mathrm{m}^{-1}\right.$ ) and Staphylococcus aureus $\left(\mathrm{MIC}=1.30 \mu \mathrm{g} \mathrm{mL}^{-1}\right.$ ) and Oliveira et al. (2020) against Streptococcus mutans, Enterococcus faecalis, Escherichia coli and Candida albicans. Carvalho, et al. (2019) observed anthelmintic activity of ethanol extract and aerial part fractions against eggs and larvae of Strongyloides venezuelensis in vitro. Conegundes, et al. (2021) verified anti-inflammatory and antinociceptive activities of the dichloromethane fraction of the leaves.

Scientific studies with $S$. guianensis verified that essential oils from stem, leaves, and fruits showed high toxicity against fourth-stage larvae of Aedes aegypti and Culex quinquefasciatus. The $\mathrm{LC}_{50}$ values obtained for the stem, leaves, and essential fruit oils were 1.76, 0.98, and $2.46 \mu \mathrm{g} \mathrm{mL}^{-1}$ against $A$. aegypti and 1.36, 0.89, and $2.45 \mu \mathrm{g} \mathrm{mL} \mathrm{m}^{-1}$ against $C$. quinquefasciatus (Aguiar et al., 2015). Ferreira, et al. (2017) verified repellent activity of volatile oil from leaves against fourth stage larvae of Achroia grisella Fabricius and Galleria mellonella Linnaeus with $\mathrm{LC}_{50}$ of $0.08 \mu \mathrm{g} / \mathrm{cm}^{2}$ and $\mathrm{LC}_{50}$ of $0.38 \mu \mathrm{g} / \mathrm{cm}^{2}$, and adult individuals of both the species at a concentration of $0.30 \mu \mathrm{g} / \mathrm{cm}^{2}$. Lourenço, et al., (2018) described the high insecticidal activity of volatile leaf oil against Spodoptera frugiperda and Anticarsia gemmatalis, which was associated with necrosis and apoptotic effects in vitro with lepidopteran cell lines, reproductive deficits (eg, lay deterrent of eggs and decreased 
egg viability), larval development (eg, inhibition of feeding) and locomotion (eg, walking activities of individual and clustered larvae). Ferreira, et al. (2019) encapsulated the volatile oil extracted from the leaves of S. guianensis in chitosan nanoparticles cross-linked with glutaraldehyde and verified increased physical stability, protection from degradation, controlled release of the oil in the control of third-stage larvae. Ae. Aegypti, having better larvicidal activity than pure oil. Moura, et al. (2021) developed cassava-based starch microparticles containing the volatile oil S. guianensis and found an increase of up to 8 days in ongoing lethal activities (more than 50\%) against third-stage larvae of the Aedes aegypti and Culex quinquefasciatus mosquitoes in comparison with pure volatile oil. According to Toledo, et al. (2019), the volatile oil from the leaves had insecticidal activity against green aphids Myzus persicae (Sulzer) with an $\mathrm{LC}_{95} 1 / 41.08 \mathrm{mg} / \mathrm{cm}^{2}$. It significantly repelled the aphids at concentrations as low as $0.14 \mathrm{mg} / \mathrm{cm}^{2}$.

There is considerable interest by the scientific community in researching the beneficial properties of S. guianensis essential oils for the development of products in the pharmaceutical area, mainly due to the growing number of studies on their antimicrobial, insecticide, and repellent activities. In general, the demand for natural products has increased the number of researches related to the elucidation of the therapeutic properties of plants, based on the study of their active constituents (Dias, et al., 2012).

This study evaluates the chemical composition and seasonal variability of volatile oil from Siparuna guianensis leaves collected in Monte do Carmo, Tocantins, Brazil.

\section{Methodology}

Leaves of Siparuna guianensis Aubl were collected until 8 am, every 20th of the month, from 10 different individuals, in the municipality of Monte do Carmo - Tocantins, Brazil (-10.71S, $-48.406 \mathrm{~W}$, at an elevation of $243.2 \mathrm{~m}$ above sea level) for 12 months (April 2019 to March 2020). The specimens of Siparuna guianensis were identified by José Realino de Paula. A voucher specimen was deposited at the Herbarium of the Federal University of Goiás, Brazil, Conservation Unit PRPPG, number UFG-72205. The leaves were dried in air circulation stove at approximately $38^{\circ} \mathrm{C}$. Climatic data for the period were obtained from the National Institute of Meteorology (INMET, 2021).

\subsection{Volatile oils}

For the extraction of essential oil, about 40 to $50 \mathrm{~g}$ of dried botanical material (leaves) was crushed with a commercial crusher (Skymsen, LS-08MB-N) immediately before extracting the essential oil, avoiding losses by volatilization and subjected to hydrodistillation in Clevenger type appliance for 3 hours. Then, the volatiles oils were desiccated with $\mathrm{Na}_{2} \mathrm{SO}_{4}$, placed in amber glass bottles, and kept at a temperature of $-18^{\circ} \mathrm{C}$ for further analysis.

The volatile oils were analyzed using a Shimadzu GC-MS QP5050A fitted with a fused silica SBP-5 (30 m x $0.25 \mathrm{~mm}$ I.D.; $0.25 \mu \mathrm{m}$ film thickness) capillary column (composed of 5\% phenylmethylpolysiloxane) and temperature- programmed as follow: $60-240^{\circ} \mathrm{C}$ at $3^{\circ} \mathrm{C} / \mathrm{min}$, then to $280^{\circ} \mathrm{C}$ at $10^{\circ} \mathrm{C} / \mathrm{min}$, ending with $10 \mathrm{~min}$ at $280^{\circ} \mathrm{C}$. The carrier gas was He at a flow rate of $1 \mathrm{ml} / \mathrm{min}$, and the split mode had a ratio of 1:20. The injection port was set at $225 \mathrm{oC}$. Significant quadrupole MS operating parameters: interface temperature $240^{\circ} \mathrm{C}$; electron impact ionization at $70 \mathrm{eV}$ with scan mass range of $40-350 \mathrm{~m} / \mathrm{z}$ at a sampling rate of $1 \mathrm{scan} / \mathrm{s}$. Constituents were identified by computer search using digital libraries of mass spectral data (NIST, 1998) and by comparison of their retention indices and authentic mass spectra (Adams, 2007), relative to C8-C32 n-alkane series in a temperature-programmed run (Van Den Dool \& Kratz, 1963).

Principal Component Analysis (PCA) was applied to examine the interrelationships between the chemical constituents of the volatile oils from leaves collected in different months using the software Statistica (Stat Soft, 2004). A hierarchical cluster analysis (HCA) was used to study the similarity of samples based on the distribution of the constituents, and 
hierarchical clustering was performed according to the method of minimum variance Ward (Ward, 1963). To validate the cluster analysis was carried out using the canonic discriminant analysis (DCA).

\section{Results}

\subsection{Volatile oils}

During the collection period, the months of less rainfall were May $(34.9 \mathrm{~mm})$, July $(0 \mathrm{~mm})$, August $(0 \mathrm{~mm})$, September $(31.5 \mathrm{~mm})$, with average temperatures ranging from $34.95^{\circ} \mathrm{C}$ to $20.26^{\circ} \mathrm{C}$. The months with the highest rainfall were October (113.6 mm), November (54.8 mm), December (84.7 mm), January (326.1 mm), February (158.3 mm), March (168.0 $\mathrm{mm}$ ), April (157.15 mm), with temperatures ranging from $34.85^{\circ} \mathrm{C}$ to $23.45^{\circ} \mathrm{C}$ (Table 1).

Table 1 - Climatic information of the period of collection of plant material of Siparuna guianensis.

\begin{tabular}{cccccc}
\hline Date & $\begin{array}{c}\text { Rainfall Precipitation } \\
\text { monthly }(\mathrm{mm})\end{array}$ & Relative humidity $(\%)$ & Daylight monthly $(\mathrm{h})$ & \multicolumn{2}{c}{ Average temperature $\left({ }^{\circ} \mathrm{C}\right)$} \\
\cline { 5 - 6 } & 157.1 & 78.36 & 185.8 & 33.36 & 23.92 \\
$05 / 2019$ & 34.9 & 69.41 & 255.5 & 34.95 & 23.92 \\
$06 / 2019$ & 0 & 56.09 & 286.9 & 35.70 & 21.26 \\
$07 / 2019$ & 0 & 50.09 & 308.5 & 35.98 & 20.26 \\
$08 / 2019$ & 0 & 42.42 & 304.8 & 37.45 & 21.30 \\
$09 / 2019$ & 31.5 & 40.82 & 253.5 & 38.71 & 24.10 \\
$10 / 2019$ & 113.6 & 67.70 & 153.9 & 34.85 & 23.85 \\
$11 / 2019$ & 54.8 & 68.83 & 165.4 & 34.84 & 24.15 \\
$12 / 2019$ & 84.7 & 68.58 & 196.6 & 34.75 & 24.10 \\
$01 / 2020$ & 326.1 & 78.31 & 143.4 & 32.57 & 23.45 \\
$02 / 2020$ & 158.3 & 70.49 & 134.7 & 32.71 & 23.73 \\
$03 / 2020$ & 168 & 77.03 & 134 & 32.42 & 23.90 \\
\hline
\end{tabular}

Source: INMET (2021). (Porto Nacional Station - OMM: 83064, Latitude: -10.71083333, Longitude: -48.40638888, Altitude: 243.28).

In the monthly analysis, $90.08 \%$ to $97.53 \%$ of the chemical compounds were identified in the volatile oils of $S$. guianensis leaves, with $21.32 \%$ to $55.44 \%$ of sesquiterpenes, 19.95 to $49.73 \%$ of oxygenated sesquiterpenes, 0.48 to $1.55 \%$ oxygenated monoterpenes, 0 to $5.67 \%$ hydrocarbon monoterpenes, 0 to $48.2 \%$ other compounds. The major compounds were $\gamma$-muurolene (13.99 to 35.97\%), Curzerene (7.22-19.15\%), Curzerenone (7.3-18.13\%), 2-undecanone (3.99-10.63) (Table 2). The isopropyl tiglate compound was the majority in December, January, February, and March (18.3 to 24.9\%) and was absent in the dry months. The compounds 2-undecanone, y-muurolene, Curzerene Curzerenone were sought in greater quantity in the dry period (Table 2). 
Research, Society and Development, v. 11, n. 1, e30011124908, 2022

(CC BY 4.0) | ISSN 2525-3409 | DOI: http://dx.doi.org/10.33448/rsd-v11i1.24908

Table 2 - Percentage of the chemical constituents of the volatile oils from Siparuna guianensis leaves collected in Monte do Carmo - TO.

\begin{tabular}{|c|c|c|c|c|c|c|c|c|c|c|c|c|c|}
\hline \multirow{2}{*}{ Compounds } & \multirow{2}{*}{ KI } & \multicolumn{9}{|c|}{2019} & \multicolumn{3}{|c|}{2020} \\
\hline & & Apr & May & Jun & July & Aug & Sep & Oct & Nov & Dez & Jan & Feb & Mar \\
\hline n-Octane & 800 & - & - & - & - & - & - & - & - & 7.8 & 8.3 & 7.2 & 5.3 \\
\hline n-Nonane & 900 & - & - & - & - & - & - & - & - & 0.4 & 0.4 & 0.3 & 0.2 \\
\hline Tricyclene & 926 & - & - & - & - & - & - & 0.3 & 0.3 & 0.3 & 0.3 & 0.3 & 0.2 \\
\hline Allyl isovalerate & 938 & - & - & - & - & - & - & - & - & 0.35 & 0.52 & 0.04 & 3.4 \\
\hline Isopropyl tiglate & 976 & - & - & - & - & - & - & - & - & 22.8 & 24.9 & 21.9 & 18.3 \\
\hline Myrcene & 990 & 5.5 & 5.02 & - & 0.2 & 0.5 & 0.3 & - & 0.3 & - & - & - & - \\
\hline$\beta$-phellandrene & 1029 & 0.1 & - & - & 0.5 & 0.5 & 0.4 & 0.5 & 0.9 & 0.5 & 0.5 & 0.7 & - \\
\hline (Z)- $\beta$ Ocimene & 1037 & - & 0.1 & - & - & - & - & - & - & - & - & - & - \\
\hline Cyclohexyl propanoate & 1134 & - & - & - & 0.4 & 0.5 & - & 1.3 & 1.4 & 0.6 & 0.96 & 1.1 & 0.6 \\
\hline n-Nonanol & 1169 & 0.3 & - & - & - & 0.9 & 0.6 & 0.2 & 2.6 & 2.2 & 2.9 & 3.1 & 1.9 \\
\hline cis-chrysanthenyl acetate & 1265 & 1.3 & 3.4 & - & - & - & - & - & - & - & - & - & - \\
\hline 2-undecanone & 1294 & 13.7 & 8.7 & - & 10.4 & 10.6 & 5.9 & 8.8 & 6.0 & 7.3 & 5.2 & 6.3 & 4.0 \\
\hline$\delta$-elemene & 1338 & 2.3 & 2.9 & 4.3 & 2.2 & 1.9 & 2.7 & 1.96 & 2.7 & 0.9 & 1.5 & 1.3 & 1.3 \\
\hline Decanoic acid & 1366 & 0.2 & - & - & - & - & - & - & - & & 1.95 & 1.98 & 0.54 \\
\hline$\beta$-burbonene & 1388 & 0.61 & 0.9 & 0.89 & 1.16 & 1.32 & 1.66 & 2.95 & 3.05 & 1.76 & 1.76 & 1.06 & 0.87 \\
\hline 1-Tetradecene & 1389 & 0.2 & - & - & - & 0.37 & - & 1.72 & 0.79 & 0.84 & 3.07 & 2.96 & 1.02 \\
\hline$\beta$-Elemene & 1390 & 0.81 & 1.27 & 1.18 & 1.19 & 1 & 1.06 & 1.07 & 1.21 & 0.53 & 0.84 & 0.93 & 0.7 \\
\hline Methyl eugenol & 1403 & 1.13 & 0.64 & 1.55 & 1.38 & 1.4 & 1.2 & 1.09 & 1.53 & 0.48 & 0.85 & 0.87 & 0.87 \\
\hline$\beta$-Ylangene & 1420 & 0.8 & 0.92 & 1.2 & 0.92 & 0.84 & 0.96 & 1.19 & 1.36 & 0.74 & 0.81 & 0.87 & 0.71 \\
\hline$\beta$-copaene & 1432 & 0.23 & 0.27 & 0.46 & - & - & - & 0.4 & 0.48 & 0.92 & - & - & - \\
\hline a-trans-Bergamotene & 1434 & - & 0.42 & - & 0.35 & - & - & - & - & - & - & - & - \\
\hline y-elemene & 1436 & 2.75 & 3.4 & 1.9 & 3.13 & 2.35 & 2.3 & 2.35 & 2.44 & 0.92 & 1.57 & 1.84 & 2.19 \\
\hline Aromadendrene & 1441 & 0.3 & 0.38 & 0.52 & - & - & - & - & - & - & - & - & - \\
\hline 6,9-guaia diene & 1444 & 0.3 & 0.47 & 0.63 & - & - & 0.46 & 0.55 & 0.64 & 0.32 & - & - & - \\
\hline y-muurolene & 1479 & 15.8 & 23.0 & 35.97 & 16.1 & 20.7 & 24.3 & 22.1 & 27.2 & 10.6 & 14.2 & 14 & 19.2 \\
\hline
\end{tabular}


Research, Society and Development, v. 11, n. 1, e30011124908, 2022

(CC BY 4.0) | ISSN 2525-3409 | DOI: http://dx.doi.org/10.33448/rsd-v11i1.24908

\begin{tabular}{|c|c|c|c|c|c|c|c|c|c|c|c|c|c|}
\hline$\beta$-selinene & 1490 & 0.28 & 0.34 & 0.43 & 0.41 & - & 0.36 & - & & - & - & - & - \\
\hline$\gamma$-amorphene & 1495 & - & 0.71 & 0.8 & - & - & - & - & - & - & - & - & - \\
\hline Curzerene & 1499 & 16.6 & 18.7 & 18.3 & 19.2 & 18.7 & 20 & 14.7 & 16.8 & 7.2 & 8.7 & 8.9 & 12.1 \\
\hline trans- $\boldsymbol{\beta}-\mathrm{Guaiene}$ & 1502 & 0.52 & 0.49 & 0.9 & 0.45 & 0.44 & 0.58 & - & 0.61 & - & - & - & - \\
\hline$\delta$-amorphene & 1512 & 0.72 & 0.78 & 1.11 & 1.05 & 0.76 & 0.89 & 0.67 & 0.76 & 1.22 & 0.44 & 0.63 & 0.81 \\
\hline y-cadinene & 1515 & 2.35 & 2.93 & 2.74 & 2.39 & 2.08 & 2.18 & 2.48 & 2.73 & 1.75 & 1.44 & 1.42 & 1.61 \\
\hline 10-epi-cubebol & 1535 & 0.43 & 0.58 & 0.6 & - & - & - & - & - & - & - & - & - \\
\hline Germacrene B & 1561 & 2.33 & 4.33 & 2.42 & 3.56 & 3.72 & 3.25 & 3.73 & 3.65 & 1.67 & 2.15 & 2.39 & 3.14 \\
\hline Espathulenol & 1578 & 0.46 & 0.88 & 0.62 & 2.03 & 1.35 & 1.1 & 1.59 & 1.28 & 4.04 & 0.92 & 1.49 & 1.1 \\
\hline Guaiol & 1600 & - & 0.81 & - & - & - & - & - & - & - & - & - & - \\
\hline Curzerenone & 1606 & 16 & 8.3 & 12.7 & 18.1 & 16.6 & 16.6 & 10.1 & 11.3 & 7.3 & 6.8 & 8.1 & 12.2 \\
\hline 1,10-di-epi-Cubenol & 1619 & - & 0.35 & 0.53 & 0.75 & 0.65 & 0.63 & 0.67 & - & - & & & - \\
\hline cis-Cadin 4-en-7-ol & 1636 & 0.42 & 0.37 & - & 1.24 & 0.94 & 0.88 & 0.79 & 0.7 & 1.87 & 0.5 & 0.93 & 0.75 \\
\hline Cubenol & 1638 & 0.62 & 0.33 & 0.62 & 0.6 & - & - & - & - & - & - & - & - \\
\hline$\alpha$-muurolol & 1646 & 2.54 & 1.56 & 2.69 & 3.08 & 2.23 & 2.49 & 1.75 & 2.2 & 3.19 & 1.31 & 1.62 & 1.74 \\
\hline$\alpha$-eudesmol & 1653 & 0.87 & 0.66 & 1.29 & 1.46 & 1.15 & 1.21 & 0.88 & 1 & 1.37 & - & - & - \\
\hline$\alpha-(Z)$-Santalol & 1675 & 0.49 & 0.25 & - & - & 0.38 & 0.41 & - & - & - & - & - & - \\
\hline Germacrone & 1693 & 3.57 & 2.88 & 0.83 & 3.29 & 3.66 & 1.73 & 2.94 & 2.07 & 1.08 & 1.65 & 1.8 & 2.74 \\
\hline Hexacosane & 2600 & - & - & - & - & - & - & 5.09 & - & - & - & 1.75 & - \\
\hline Octacosane & 2800 & - & - & - & - & - & - & 4.2 & - & - & - & 1.59 & - \\
\hline Monoterpene hydrocarbons & & 5.67 & 5.13 & 0 & 0.66 & 0.98 & 0.74 & 0.81 & 1.41 & 0.78 & 0.85 & 0.95 & 0.21 \\
\hline Oxygenated Monoterpenes & & 1.13 & 0.64 & 1.55 & 1.38 & 1.4 & 1.2 & 1.09 & 1.53 & 0.48 & 0.85 & 0.87 & 0.87 \\
\hline Sesquiterpene hydrocarbons & & 30.1 & 43.5 & 55.4 & 32.9 & 35.1 & 40.7 & 39.5 & 46.8 & 21.3 & 24.7 & 24.4 & 30.5 \\
\hline Oxygenated sesquiterpenes & & 41.9 & 35.6 & 38.2 & 49.7 & 45.7 & 45.0 & 33.4 & 35.3 & 26.1 & 20.0 & 22.8 & 30.7 \\
\hline Others & & 15.7 & 12.1 & 0 & 10.74 & 12.4 & 6.5 & 21.3 & 10.8 & 42.2 & 48.2 & 48.2 & 35.2 \\
\hline Total & & 94.5 & 97.0 & 95.2 & 95.4 & 95.6 & 94.2 & 96.1 & 95.9 & 90.9 & 94.5 & 97.3 & 97.5 \\
\hline Yield (\%) & & 0.3 & 0.4 & 0.3 & 0.2 & 0.3 & 0.4 & 0.2 & 0.3 & 0.1 & 0.2 & 0.3 & 0.4 \\
\hline
\end{tabular}

Source: Authors. 
The results obtained in the PCA and the cluster analysis showed chemical variability between samples of volatile oils obtained from leaves of $S$. guianensis (Figure1). Figure 2 indicates that the relative position of the 2D axis originated at the PCA. This analysis suggests that cluster I, broken down by curzerenone, $\beta$-selinene, $\delta$-elemene, corresponds to the months with the lowest rainfall (April, May, June, July, August, and September), and cluster II, broken down by $\beta$-burbonene corresponds to the months with the highest rainfall (October, November, January, February, and March) (Table 2).

Figure 1 - Dendrogram representing the chemical composition similarity relationships of Siparuna guianensis leaves volatiles oils according to Ward's variance minimization method.

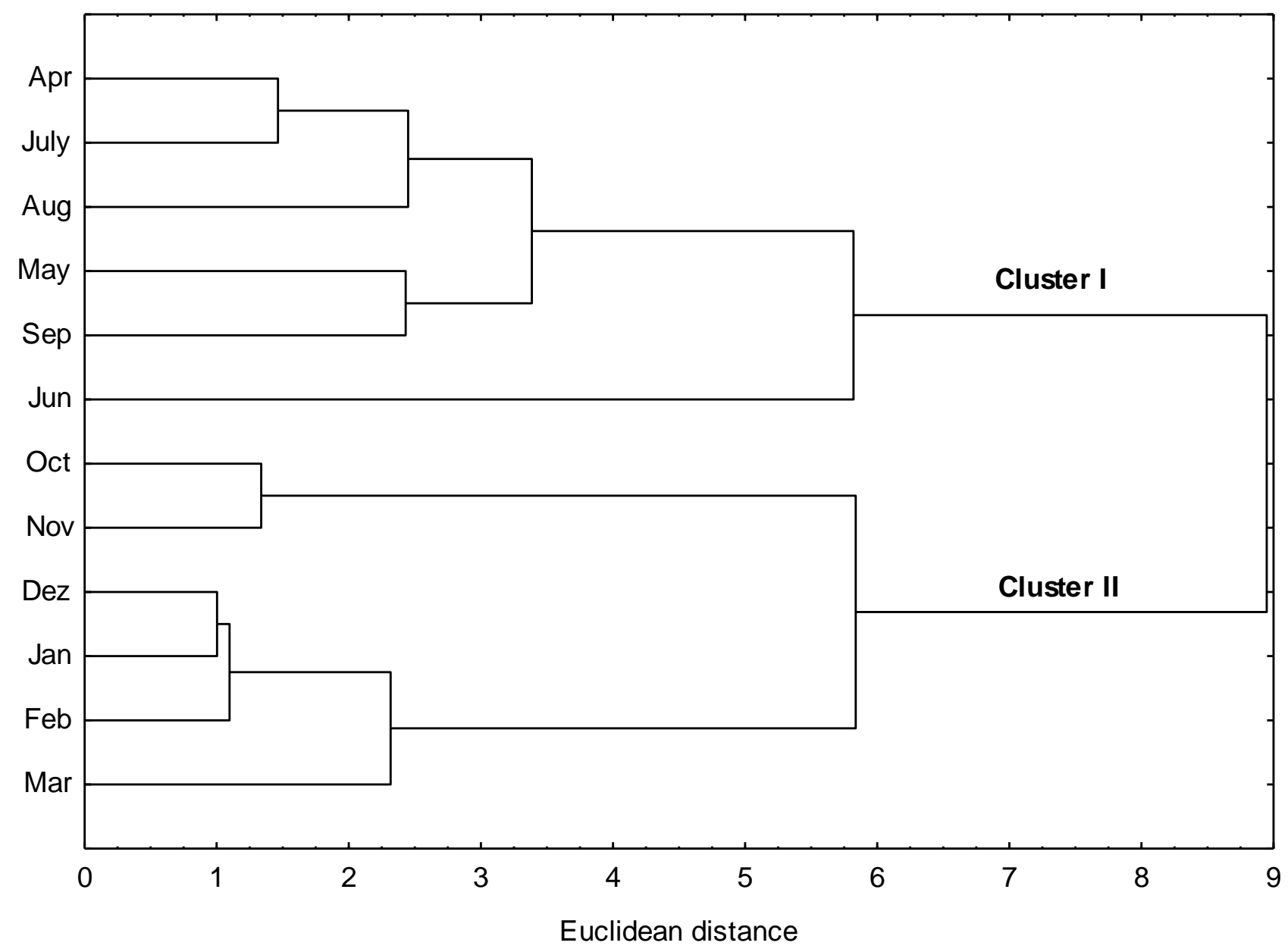

Source: Authors. 
Figure 2 - Scatterplot from PCA of leaves of Siparuna guianensis, samples collected from Monte do Carmo - TO belonging to the clusters I, and II. a. Axes refer to scores from the samples; b. Axes refer to scores from discriminant oil constituents represented as vectors from the origin.

PC- $1^{b}$

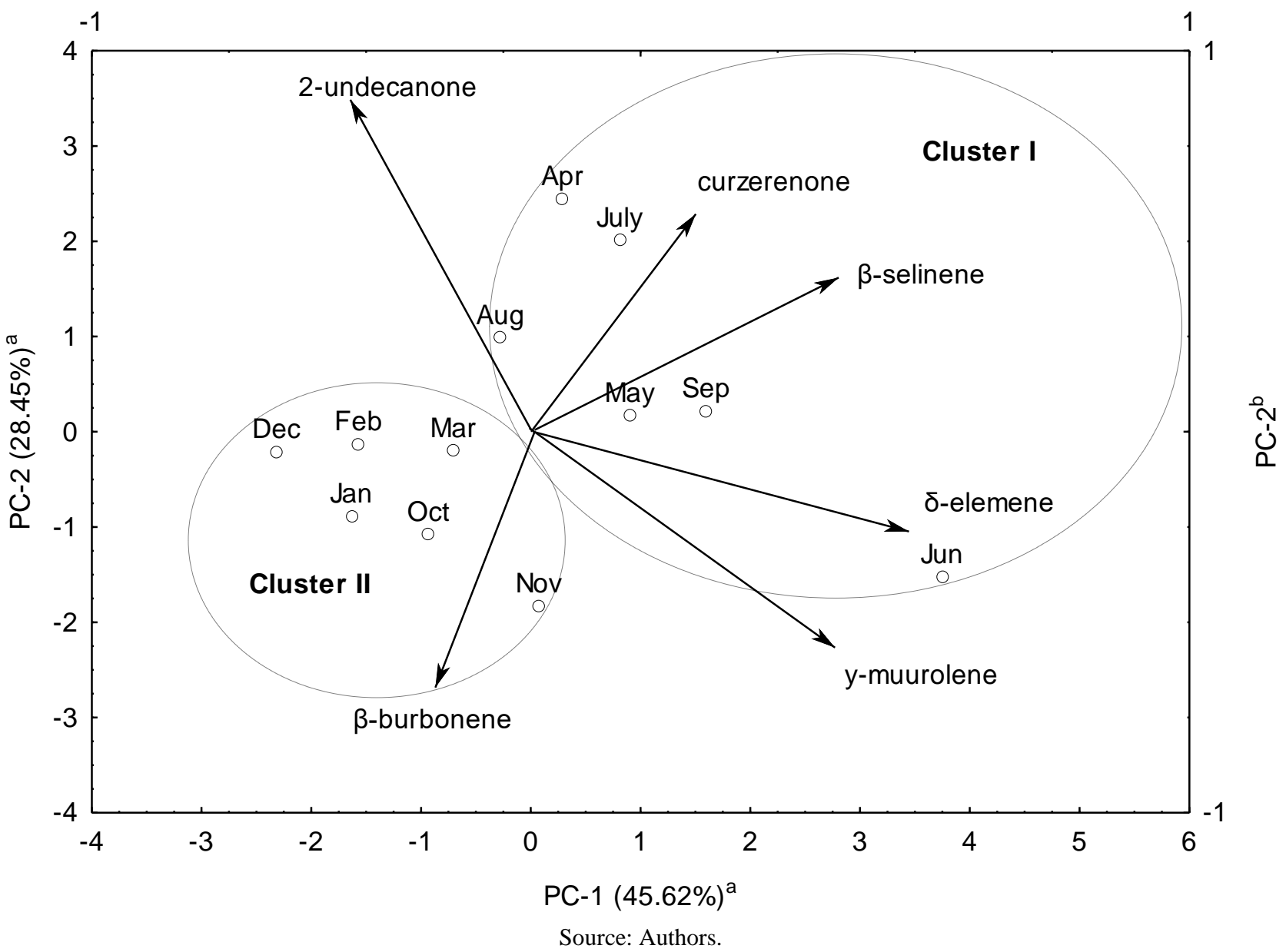

Canonic discriminant analysis was performed to help predict the cluster analysis's grouping, and two predictive variables were employed: $\delta$-elemene, and curzerenone; the two discriminant functions retain $91.7 \% \%$ of well - classification in the original clusters by a cross-validation approach Table 3). Thus, the canonic discriminant analysis revealed that the classification proposed, and the variables employed are suitable to show that the findings of the HCA and the PCA were consistent. Besides, among the independent variables, $\delta$-elemene and curzerenone presented a higher mean in the dry period (cluster I) when compared to cluster II. 
Research, Society and Development, v. 11, n. 1, e30011124908, 2022

(CC BY 4.0) | ISSN 2525-3409 | DOI: http://dx.doi.org/10.33448/rsd-v11i1.24908

Table 3 - Canonical discriminant analysis summary of leaves volatile oil from Siparuna guianensis.

\begin{tabular}{|c|c|c|c|c|}
\hline \multicolumn{5}{|c|}{ Canonical discriminant } \\
\hline & Eingenvalues functions & Canonical R & Wilk's Lambda & $p$-level \\
\hline $\mathrm{F} 1$ & 2.21 & 0.83 & 0.3108 & 0.0052 \\
\hline \multicolumn{5}{|c|}{ Standardized Coefficients for Canonical Variables } \\
\hline$\delta$-elemene & -0.014 & & & \\
\hline curzerenone & -0.99 & & & \\
\hline Cumulative Proportion & 1.0 & & & \\
\hline \multicolumn{2}{|c|}{ Percent of total well-classification } & Cluster I & Cluster II & \\
\hline & & $\mathrm{p}=0.5$ & $\mathrm{p}=0.5$ & \\
\hline Cluster I & $83.3 \%$ & 5 & 1 & \\
\hline Cluster II & $100 \%$ & 0 & 6 & \\
\hline Total & $91.7 \%$ & 5 & 7 & \\
\hline
\end{tabular}

Source: Authors.

\section{Discussion}

The major compounds found in the present study were $\gamma$-muurolene, curzerene, curzerenone, 2-undecanone. The isopropyl tiglate was the majority compound in December, January, February, and March (18.3 to 24.9\%) and was absent in the dry months. The compounds 2-undecanone, y-muurolene, curzerene, and curzerenone were produced in greater quantity in the dry period. It was verified the presence of two clusters, one in the dry season and the other in the rainy season. Viana, et al. (2002) extracted essential oils from leaves, root bark, stem bark, stem wood, root wood, and fruits of S. guianensis collected in Amapá, northern Amazon Forest, Brazil, and identified monoterpenes, sesquiterpenes, sesquiterpene alcohols, and two aliphatic ketones, 2 -undecanone and 2 -tridecanone. $\alpha$-Pinene, myrcene, $y$-cadinene, epi- $\alpha$-cadinol were present in all samples. Still, epi- $\alpha$-cadinol (11.9-39.9\%) was the main component except for stem bark and oils of the fruits, where terpinolene (33.4\%), and 2-undecanone (52.7\%) were the majority, respectively. Zoghbi (1998) identified as the main constituents of the volatile oils from the leaves of S. guianensis collected in Moju, Pará, Brazil, the epi- $\alpha$-bisabolol (25.1\%) and spathulenol (15.7\%), from the leaves collected in Rio Branco (AC) the spathulenol (22\%), selin-in-4 $\alpha$-ol (19.4\%), $\beta$-eudesmol (10\%) and lemol (10\%), and from those collected in Belém (PA), the germacrone (23.2\%), germacrene D (10.9\%), bicyclogermacrene $(8.6 \%)$, and atractilone (31.4\%). The main components of essential oils from the leaves of S. guianensis collected in Gurupi and Formoso do Araguaia, Tocantins, Brazil, were $\beta$-myrcene (79.71\%) and 2-undecanone (14.58\%), from the stem, were $\beta$ myrcene $(26.91 \%)$, $\delta$-elemene $(20.92 \%)$, germacrene D $(9.42 \%), \alpha$-limonene $(7.91 \%)$ and bicyclogermacrene $(7.79 \%)$ and from fruits, 2 -tridecanone (38.75\%), 2-undecanone (26.5\%) and $\beta$-myrcene (16.42\%) (Aguiar, et al., 2015); of the leaves collected in Lavras, Minas Gerais, Brazil were $\beta$-myrcene (13.14\%), germacrene-D (8.68\%) and bicyclogermacrene (16.71\%) (Andrade, et al., 2015); of the leaves collected in Gurupi, Tocantins, Brazil were $\beta$-myrcene (45.62\%) and 2-undecanone (17.87\%) (Ferreira et al., 2017). Melo, et al. (2017) verified in the volatile oil of fresh leaves of S. guianensis collected in Machado, Minas Gerais, the myrcene (1-16.0\%), germacrene-D (2-10.0\%), E,E-farnesol (3 - 18.0\%) and siparunone (4-14.6 $\%)$; Ferreira et al. (2019) from leaves collected in Gurupi, Tocantins, Brazil, the $\beta$-myrcene (48.6\%) and epicurzerenone (19.3\%), Toledo et al. (2019) observed from leaves collected in Gurupi, Tocantins o $\beta$-myrcene (69.30\%) and 2-undocanone $(8.37 \%)$. Moura, et al. (2020) identified in leaves collected in Porto Nacional, Tocantins, Brazil, $\beta$-mircene (39.67\%), germacrene D (14.34\%) and epicurzerenone (18.16\%); Oliveira, et al. (2020) from leaves collected in Belém, Pará o trans- $\beta$ - 
Research, Society and Development, v. 11, n. 1, e30011124908, 2022

(CC BY 4.0) | ISSN 2525-3409 | DOI: http://dx.doi.org/10.33448/rsd-v11i1.24908

elemenone (11.78\%), atractilone (18.65\%), $\delta$-elemene (5.38\%), $\beta$-elemene $(3.13 \%), \beta$-yerani $(4.14 \%), \gamma$-elemene $(7.04 \%)$, germacrene D (7.61\%), curzerene (7.1\%), and germacrona (5.26\%) and Morura, et al, (2021) from leaves collected in Gurupi, Tocantins o $\beta$-myrcene (39.16\%) ), epicurzerenone (16.02\%) and $\beta$-copaene $(9.33 \%)$.

Valentini, et al. (2010) evaluated the seasonal variation of volatile oil from S. guianensis leaves collected in Bosque Paulo Siqueira in Cuiabá MT, between November 2007 and October 2008, and found siparunone as major compounds (21.09 to $59.5 \%$ ), spathulenol (2.8 to $17.21 \%$ ), dihydrocarvyl acetate (5.4 to $23.89 \%$ ), caryophyllene oxide (2.25 to $19.44 \%$ ), viridiflorol (0.56 to $26.47 \%)$, ledol (1.22 to $10.49 \%)$, limonene dioxide (1.74 to $10.81 \%)$ and 1,2-benzenedioic acid (0. 75 to $5.87 \%$ ). As for the classes of compounds, they presented 1.74 to $10.81 \%$ of oxygenated monoterpenes, 1.35 to $5.23 \%$ of sesquiterpenes, 47.03 to 80.74 of oxygenated sesquiterpenes, and other non-terpenic compounds from 0.31 to $31.76 \%$. In the essential oils from S. guianensis leaves collected in Cuiabá - MT, siparunone was the major component, with a monthly mean equal to $41.64 \pm 12.68$ (SD), and with the highest production in June 2008 , season dry, with the lowest maximum and minimum temperatures. Ledol was identified in the samples of all months, and spathulenol was not identified only in August 2008 , and they were identified in greater quantity in the dry-rainy transition season. These compounds identified in practically all monthly samples (siparunone, ledol and spathulenol) had a lower yield in the rainy months. Caryophyllene oxide, 1,2benzenedioic acid, and dihydrocarvyl acetate had their highest production in the dry season (August 2008), where the highest average maximum temperature of the year was registered.

Comparing this study with data from the literature, it is concluded that S. guianensis has great chemical variability, which can be explained by genetic factors, seasonality, light, temperature, water availability, nutrition, herbivory, which can alter the production of metabolites (Gobbo-Neto \& Lopes, 2007; Lima, et al., 2003).

\section{Conclusion}

As $S$. guianensis has broad therapeutic potential as an antimicrobial and promising larvicidal activity, there is a need for agronomic studies of soil, temperature, and light control to obtain specimens that produce interesting chemical compounds in greater quantities for the pharmaceutical industry. This study is the first carried out with oils from leaves collected in Monte do Carmo, Tocantins, Brazil. The results obtained here help to guide the best times for collecting leaves of the S. guianensis species and understanding the chemical variability profile of this species related to seasonality. We suggest more studies of the biological activities of purified major compounds in the search for active markers for products to be developed from $S$. guianensis.

\section{Acknowledgments}

The authors are grateful for the financial support of the Coordination for the Improvement of Higher Education Personnel - Brazil (CAPES), the National Council for Scientific and Technological Development (CNPq), and the Foundation for Research Support of the State of Goiás (FAPEG). This study was funded in part by CAPES, Finance Code 001.

\section{References}

Adams, R. P. (2007). Identification of essential oil components by Gas Chromatography/Mass Spectroscopy. (4th ed.) Carol Stream, IL: Allured Publ. Corp.

Aguiar, R. W. S., Santos, S. F. S., Morgado, F. S., Ascencio, S. D., Lopes, M. M., Viana, K. F., Didonet, J. \& Ribeiro, B. M. (2015). Insecticidal and repellent activity of Siparuna guianensis Aubl. (Negramina) against Aedes aegypti and Culex quinquefasciatus, PLOS ONE 3, 1-14.

Andrade, M. A., Cardoso, M. G., Gomes, M. S., Azeredo, C. M. O., Batista, L. R., Soares, M. J. S., Rodrigues, L. M. A. \& Figueiredo, A. C. S. (2015). Biological activity of the essential oils from Cinnamodendron dinisii and Siparuna guianensis. Brazilian Journal of Microbiology, 46(1), 189-194. 
Research, Society and Development, v. 11, n. 1, e30011124908, 2022

(CC BY 4.0) | ISSN 2525-3409 | DOI: http://dx.doi.org/10.33448/rsd-v11i1.24908

Bieras, A. C. \& Sajo, M. G. (2009). Leaf structure of the cerrado (Brazilian savanna) woody plants. Trees, 23, 451-471.

Carvalho, M. G. T. \& Vilarinho, C. S. P. S. (2017). Plantas medicinais: o ouro do nosso Cerrado. Goiânia: Kelps. 222p.

Carvalho, V. F., Ramos, L. A., Silva, C. A, Nebo, L., Moraes D., Silva, F. F. A., Costa, N. C. A., Rodrigues Junior, R. O. Souza, L. F. \& Rodrigues, R. M. (2019). In vitro anthelmintic activity of Siparuna guianensis extract and essential oil against Strongyloides venezuelensis. Journal of Helminthology, 94, e50, 1-5. https://doi.org/10.1017/S0022149X19000282

Conegundes, J. L. M., Silva, J. M., Mendes, R. F., Fernandes, M. F., Pinto, N. C. C., Almeida, M. A., Dib, P. R. B., Andrade, R. O., Rodrigues, M. N., Castãnon, M. C. M. N., Macedo, G. C. \& Scio, E. (2021). Anti-inflammatory and antinociceptive activity of Siparuna guianensis Aublet, an Amazonian plant traditionally used by indigenous communities. Journal of Ethnopharmacology 265 (113344), 1-12.

De La Cruz, M. G. (2008). Plantas Medicinais de Mato Grosso: A farmacopeia popular dos raizeiros. Carlini \& Caniato. 224p.

Dias, D. A., Urban, S. \& Roessner, U. (2012). A historical overview of natural products in drug discovery. Metabolites, 2 (2), 303-336.

Ferreira, T. P., Haddi, K., Corrêa, R. F. T., Zapata, V. L. B., Piau, T. B., Souza, L. F. N., Santos, S. G., Oliveira, E. E., Jumbo, L. O. V., Ribeiro, B. M., Grisolia, C. K., Fidelis, R. R., Maia, A. M. S., Raimundo W. S. \& Aguiar, R. W. S. (2019). Prolonged mosquitocidal activity of Siparuna guianensis essential oil encapsulated in chitosan nanoparticles. PLoS Neglected Tropical Diseases, 13(8), 1-23. https://doi.org/10.1371/journal.pntd.0007624

Facundo, V. A., Azevedo, M. S., Rodrigues, R. V., Nascimento, L. F., Militão, J. S. L. T., Silva, G. V. J. \& Braz-Filho, R. (2012). Chemical constituents from three medicinal plants: Piper renitens, Siparuna guianensis and Alternanthera brasiliana. Brazilian Journal of Pharmacognosy, 22(5), 1134-1139. 2012

INMET (2021). Instituto Nacional de Meteorologia. Ministério da agricultura, pecuária e abastecimento. http://www.inmet.gov.br/portal/ (acessado em setembro de 2021).

Kuhlmann, M. (2012). Frutos e sementes do Cerrado atrativos para fauna: guia de campo. Ed. Rede de Sementes do Cerrado. 360p.

Leitão, G. G., El-Adji, S. S., Melo, W. A. L. \& Brown, S. G. L. L. (2005). Separation of free and glycosylated flavonoids from Siparuna guianensis by gradient and isocratic CCC. Journal of Liquid Chromatography \& Related Technologiesw, 28, 2041-2051.

Lourenço, A. M., Haddi, K., Ribeiro, B. M., Corrêia, R. F. T., Tomé, H. V. V., Santos-Amaya, O., Pereira, E. J. G., Guedes, R. N. C., Santos, G. R., Oliveira, E. E. \& Aguiar. R. W. S. (2018). Essential oil of Siparuna guianensis as an alternative tool for improved lepidopteran control and resistance management practices. Scientific Reports, 8(7215), 1-13. https://doi.org/10.1038/s41598-018-25721-0.

Marti, G., Eparvier, V., Morleo, B., Le Ven, J., Apel, C., Bodo, B., Amand, S., Dumontet, V., Lozach, O., Meijer, L., Françoise Guéritte, F. \& Marc Litaudon, M. (2013). Natural aristolactams and aporphine alkaloids as inhibitors of CDK1/Cyclin B and DYRK1A. Molecules, 18, 3018-3027. https://doi:10.3390/molecules18033018.

Melo, D. C., Miranda, M. L. D., Ferreira, W. G., Andrade, P. (2017). Anticariogenic and antimycobacterial activities of the essential oil of Siparuna guianensis Aublet (Siparunaceae). Orbital: The Electronic Journal of Chemistry, 1-7.

Moura, W. S., Oliveira, E. E., Haddi, K., Corrêa, R. F. T., Piau, T. B., Moura, D. S., Santos, S. F., Grisolia, C. K., Ribeiro, B. M., Aguiar, R. W. S. (2021). Cassava starch-based essential oil microparticles preparations: Functionalities in mosquito control and selectivity against non-target organisms. Industrial Crops \& Products, 162 (2021) 113289, 1-10.

NIST (1998). National Institute of Standards and Technology, PC version of the NIST/ EPA/NIH Mass Spectral Database. U.S. Gaithersburg: Department of Commerce.

Oliveira, M. S., Cruz, J. N., Costa, W. A., Silva, S. G., Brito, M. P., Menezes, S. A. F., Chaves Neto, A. M. J., Andrade, E. H. A. \& Carvalho Junior, R. N. (2020). Chemical composition, antimicrobial properties of Siparuna guianensis essential oil and a molecular docking and dynamics molecular study of its major chemical constituent. Molecules, 25(3852), 1-15. https://doi:10.3390/molecules25173852.

Portella, A. C. F., Munaro, M., Ascêncio, S. D., Siqueira, C. A., Ferreira, T. P. S., Aguiar, R. W. S. (2014). Caracterização físico-química do óleo essencial da Siparuna guianensis Aublet. Química Nova, 37, (5), 844-849.

Simas, N. K., Ferrari, S. F., Pereira, S. N. \& Leitão, G. G. (2001). Chemical ecological characteristics of herbivory of Siparuna guianensis seeds by buffyheaded marmosets (Callithrix flaviceps) in the atlantic forest of southeastern Brazil. Journal of Chemical Ecology, 27 (1), 93-107.

Taylor, P. G., Cesari, I. M., Arsenak, M., Ballen, D., Abad, M. J., Fernandez, A., Milano, B., Ruiz, M., Williams, B. \& Michelangeli, F. (2006). Evaluation of Venezuelan medicinal plant extracts for antitumor and antiprotease activities. Pharmaceutical Biology, 44(5), 349-362.

Toledo, P. F. S., Ferreira, T. P., Bastos, I. M. A. S., Rezende, S. M., Jumbo, L. O. V., Julcemar Didonet, J., Bruno S. Andrade, B. S., Tarcisio S. Melo, T. S., Smagghe, G., Oliveira, E. E. \& Aguiar R.W.S. (2019). Essential oil from negramina (Siparuna guianensis) plants controls aphids without impairing survival and predatory abilities of nontarget ladybeetles. Environmental Pollution, 255 (113153), 1-12.

Valentini, C. M. A., Silva, L. E., Maciel, E. N., Franceschini, E., Sousa Jr., P. T., Dall’oglio, E. L. \& Coelho, M. F. B. (2010). Variação anual do rendimento e composição química dos componentes voláteis da Siparuna guianensis Aublet. Química Nova, 33 (7), 1506-1509.

Van Den Dool, H. \& Kratz, P. D. (1963). A generalization of the Retention Index system including linear temperature programmed gas - liquid partition chromatography. Journal of Chromatography, 11, 463-471. https://doi.org/10.1016/S0021-9673(01)80947-X

Ward, J. H. (1963). Hierarchical grouping to optimize an objective function. Journal of the American Statistical Association, 58, 236-244. 
Research, Society and Development, v. 11, n. 1, e30011124908, 2022

(CC BY 4.0) | ISSN 2525-3409 | DOI: http://dx.doi.org/10.33448/rsd-v11i1.24908

https://doi.org/10.1080/01621459.1963.10500845

Zoghbi, M. G. B., Andrade, E. H. A., Santon, A. S., Silva, M. H. L. \& Maia, J. B. S. (1998). Essential oils of Siparuna guianensis Aubl. Journal of Essential Oil Research, 10, 543-546. 